\title{
Hubungan Persepsi Anak Mengenai Dukungan Sosial Orangtua Dengan Sikap Anak Terhadap Perilaku Mengkonsumsi Buah
}

\author{
Mina Henrietty Anindia \& Endang Fourianalistyawati \\ Fakultas Psikologi Universitas YARSI \\ J1. Letjen Suprapto Kav 13, Cempaka Putih Jakarta 10510 \\ mina.anindia@gmail.com; endang.fouriana@yarsi.ac.id
}

\begin{abstract}
This research was conducted based on the phenomenon where children are more familiar with foods that have a low nutrient content. Fruit is a healthy food intake component that has many benefits. Child feeding behavior relate to the role of parents in providing social support, including the support provided in the form of emotional support, self-esteem, instrumental, informational, and social networking. Attitude is the evaluation of various aspects of the social world that includes the people around, objects, and ideas. Attitudes are formed from the components of affective, cognitive, and behavioral. All three components must be consistent with one another, so that alignment occurs in the formation of attitudes. Children have the ability to see and judge others, it is called social perception. A total of 70 elementary school students ranging in age from 9-11 years participated in the study. Children with the age range has been progressing more advanced cognitively and socially. In this study, the scale of the study was made by researchers. The results showed that there was a significant relationship between children's perception of the social support parents with children's attitudes towards the consumption of fruit. Thus, it was suggested to the parties concerned to participate to make efforts to increase consumption of fruit in children, as a way to maintain health.
\end{abstract}

Keywords: children's perception;parental social support;consuming fruit

Abstrak-Penelitian ini dilakukan berdasarkan fenomena di mana anak lebih akrab dengan makanan yang memiliki kandungan gizi rendah. Buah merupakan salah satu komponen asupan makanan sehat yang memiliki banyak manfaat. Perilaku makan anak berhubungan dengan peran orangtua dalam memberikan dukungan sosial. Dukungan sosial yang diberikan berupa dukungan emosional, penghargaan diri, instrumental, informasional, dan jaringan sosial. Sikap merupakan evaluasi berbagai aspek dalam dunia sosial yang meliputi orang-orang di sekitar, objek, dan ide-ide. Sikap terbentuk dari komponen afektif, kognitif, dan perilaku. Ketiga komponen tersebut harus konsisten satu dengan yang lain, agar terjadi keselarasan dalam pembentukan sikap. Anak memiliki kemampuan untuk melihat dan menilai orang lain, disebut juga sebagai persepsi sosial. Sebanyak 70 siswa sekolah dasar dengan rentang usia 9-11 tahun berpartisipasi dalam penelitian ini. Anak dengan rentang usia tersebut telah mengalami perkembangan yang lebih maju secara kognitif maupun sosial. Dalam penelitian 
ini, skala penelitian dibuat sendiri oleh peneliti. Hasil penelitian menunjukkan bahwa terdapat hubungan yang signifikan antara persepsi anak mengenai dukungan sosial orangtua dengan sikap anak terhadap konsumsi buah. Dengan demikian, disarankan kepada pihak-pihak terkait untuk turut serta melakukan upaya-upaya meningkatkan konsumsi buah pada anak-anak, sebagai salah satu cara menjaga kesehatan.

Kata kunci: persepsi anak; dukungan sosial orangtua; konsumsi buah.

\section{PENDAHULUAN}

\section{Latar Belakang}

Tubuh manusia memerlukan asupan makanan sehat yang memiliki beberapa fungsi untuk menghasilkan energi yang dibutuhkan manusia dalam beraktivitas. Komponen gizi seimbang yang sehat terdiri dari karbohidrat, protein, lemak, vitamin dan mineral, dalam jumlah yang cukup. Adapun komponen asupan makanan sehat menurut Ogden (2007) antara lain adalah buah-buahan, sayur-sayuran, roti, pasta, sereal, kentang, daging, ikan, susu dan produknya, serta sedikit makanan berlemak dan memiliki rasa manis. Menurut Aswatini, Noveria, dan Fitranita (2008), terdapat pedoman umum gizi seimbang di Indonesia, yang terbagi menjadi sumber zat tenaga (kelompok padi-padian, umbi-umbian, dan tepung-tepungan), sumber zat pengatur (kelompok buah-buahan dan sayuran), dan sumber zat pembangun (kelompok kacang-kacangan, produk makanan hewani dan olahannya).

Fenomena yang terjadi beberapa waktu belakangan adalah masih banyak anak terutama yang tinggal di kota besar, lebih akrab dengan makanan cepat saji yang mengandung lemak tinggi, serta tidak mengandung komponen gizi yang tepat. Dampak dari mengkonsumsi jenis makanan tersebut, anak menjadi rentan terkena penyakit yang berhubungan dengan pencernaan dan metabolisme. Anak yang terbiasa mengkonsumsi makanan tidak sehat, berpotensi untuk mengalami obesitas. Menurut Susana dan Hadiyono (2002), permasalahan lain yang dihadapi yaitu masalah kekurangan dan kelebihan gizi akibat perubahan gaya hidup dan pola makan. Pola makan yang tidak sehat pada masa kanak-kanak juga berhubungan dengan kesehatan fisik maupun psikologis. Kebiasaan makan berpengaruh terhadap kemungkinan obesitas pada masa kanak-kanak maupun masa dewasa. Hal tersebut memungkinkan munculnya penyakit kanker, kardiovaskuler, dan penyakit lainnya. Selain kondisi fisik, masalah gizi dapat mempengaruhi perkembangan mental dan kecerdasan.

Berdasarkan penjelasan tersebut, dapat disimpulkan bahwa kebiasaan anak dalam mengkonsumsi jenis makanan tidak sehat, dapat menyebabkan berbagai jenis penyakit yang merugikan kesehatan. Tubuh membutuhkan energi dari makanan yang berkualitas, yang salah satunya adalah buah.

Buah, sebagai salah satu komponen asupan makanan sehat, juga memiliki peranan penting dalam menjaga kesehatan tubuh (Aswatini dkk., 2008). Berdasarkan food guide pyramid, buah berfungsi sebagai sumber utama zat gizi mikro, sebagai zat pengatur. Selain itu, sebuah penelitian menjelaskan mengenai zat potasium dan vitamin $\mathrm{C}$ yang terkandung di dalam buah, berperan dalam menurunkan risiko penyakit stroke, penyakit jantung, menurunkan tekanan darah, dan kanker. Menurut Ahmad (2011), vitamin C juga berfungsi untuk penyerapan zat besi, yang jika kekurangan vitamin $\mathrm{C}$ beresiko terkena anemia dan kelemahan tulang.

Menurut Badan Perencanaan Nasional (Bappenas) (2007), konsumsi buah penduduk Indonesia lebih sedikit dari jumlah yang dianjurkan. Hasil penelitian Sartika (2011) menunjukkan bahwa sekitar $90 \%$ anak Indonesia mengkonsumsi buah dengan ukuran $<3$ porsi per hari. Berdasarkan acuan diet menurut Bappenas (2007), konsumsi buah per hari adalah sebanyak $120 \mathrm{kkal}$. Namun, dalam kenyataannya, penduduk Indonesia secara keseluruhan hanya mengkonsumsi sekitar 65\%-79\% dari anjuran. 
Tabel 1. Perbandingan Konsumsi Pangan dan Aktual 1999-2007 di Indonesia (kkal/kapita/hari) (Bappenas, 2007)

\begin{tabular}{lcccccc}
\hline & \multicolumn{7}{c}{ Konsumsi Aktual } \\
\hline $\begin{array}{l}\text { Kelompok } \\
\text { Pangan }\end{array}$ & Anjuran & $\mathbf{2 0 0 2}$ & $\mathbf{2 0 0 3}$ & $\mathbf{2 0 0 4}$ & $\mathbf{2 0 0 5}$ & $\mathbf{2 0 0 7}$ \\
\hline Padi-padian & 1000 & 1253 & 1252 & 1248 & 1241 & 953 \\
Umbi-umbian & 120 & 70 & 66 & 77 & 73 & 52 \\
Pangan hewani & 240 & 117 & 138 & 134 & 139 & 146 \\
Minyak+lemak & 200 & 205 & 195 & 195 & 199 & 246 \\
Kacang-kacangan & 100 & 62 & 62 & 64 & 67 & 73 \\
Gula & 100 & 96 & 101 & 101 & 99 & - \\
Sayur+buah & 120 & 78 & 90 & 87 & 93 & 95 \\
Lain-lain & 60 & 53 & 32 & 33 & 35 & 449 \\
\hline
\end{tabular}

Berdasarkan hasil survei sosial ekonomi nasional (BPS, 2012), jumlah konsumsi buah-buahan di provinsi DKI Jakarta mengalami penurunan dari tahun 2009 hingga 2010. Hal tersebut dapat dilihat berdasarkan tabel berikut ini.

Tabel 2. Rata-rata Pengeluaran per Kapita per Bulan Menurut Kelompok Makanan di Provinsi DKI Jakarta (BPS, 2012)

\begin{tabular}{|c|c|c|}
\hline Kelompok Bahan Makanan & 2009 & 2010 \\
\hline Padi-padian & 9,65 & 9,34 \\
\hline Umbi-umbian & 0,58 & 0,48 \\
\hline Ikan & 5,78 & 5,46 \\
\hline Daging & 5,45 & 5,09 \\
\hline Telur dan susu & 8,94 & 8,19 \\
\hline Sayur-sayuran & 4,75 & 4,95 \\
\hline Kacang-kacangan & 2,68 & 2,31 \\
\hline Buah-buahan & 4,54 & 3,91 \\
\hline Minyak dan lemak & 2,49 & 2,22 \\
\hline Bahan minuman & 2,62 & 2,65 \\
\hline Bumbu-bumbuan & 1,19 & 1,13 \\
\hline Konsumsi lainnya & 2,47 & 2,58 \\
\hline Makanan \& minuman jadi & 39,14 & 42,18 \\
\hline Minuman beralkohol & 0,07 & 0,08 \\
\hline Tembakau dan sirih & 9,65 & 9,43 \\
\hline Jumlah pengeluaran kelompok bahan makanan & 100 & 100 \\
\hline
\end{tabular}

Adapun faktor-faktor yang mempengaruhi kebiasaan makan anak menurut Wardiatmo (dalam Khomsan, Anwar, Sukandar, Riyadi \& Mudjajanto, 2006), antara lain adalah perbedaan etnis, tingkat sosial ekonomi, geografi, iklim, agama, kepercayaan, dan kemajuan teknologi. Faktor-faktor tersebut tidak lepas 
dari pengaruh lingkungan sekitar tempat anak tinggal. Selain itu kebiasaan mengkonsumsi buah pada anak tidak dibiasakan sejak dini, sehingga perlu sebuah upaya agar generasi muda memiliki kesadaran untuk mengkonsumsi buah.

Menurut Papalia, Olds, Sally dan Feldman (2009), anak usia 9-11 tahun secara kognitif telah memiliki kemampuan untuk mempertimbangkan banyak sudut pandang serta mulai memiliki strategi ingatan yang meningkat. Secara perkembangan sosial, pada tahapan usia 9-11 tahun, anak dan orangtua mulai membagi pengaturan perilaku sehingga orangtua memiliki peran dalam mendukung kebiasaan sehat pada anak yang dimulai sejak dini.

Menurut Sellis dan Nander (dalam Susana dan Hadiyono, 2002), interaksi antara orangtua dan anak mempunyai pengaruh besar terhadap perilaku makan, status gizi, dan juga perkembangan psikologis anak. Pentingnya dukungan orangtua terhadap pengembangan perilaku makan sehat anak, telah dibuktikan oleh Epstein, Valoski dan Wing (1996). Hasil penelitiannya menunjukkan bahwa melalui partisipasi aktif dari orangtua, yaitu dengan memberi contoh dan turut serta dalam melakukan kebiasaan makan yang sehat, anak akan mengikuti kebiasaan sehat tersebut. Maka, menciptakan interaksi dan situasi yang menyenangkan pada saat makan bersama sangat penting untuk diwujudkan.

Menurut Susana dan Hadiyono (2002), orangtua memiliki peran dalam memberikan dukungan sosial pada anak. Sebagai bentuk dukungan terhadap anak agar melakukan perilaku sehat, peran orangtua antara lain memberikan peraturan, disiplin, hadiah, dan hukuman yang berpengaruh terhadap interaksi antara orangtua dengan anak. Selain itu, orangtua berperan dalam memberikan dukungan emosional sehingga sebuah proses pendekatan mengenai kebiasaan sehat, seperti perilaku makan sehat, akan tercipta dengan baik. Norrell (1984) menjelaskan bahwa orangtua sebagai bagian dalam suatu keluarga, berperan dalam mengajarkan berbagai hal pada anak. Dukungan sosial merupakan suatu bentuk hubungan antara orangtua dengan anak, di mana orangtua memberikan dukungan secara emosional, informasional, instrumental, penghargaan diri, dan dukungan jaringan sosial terhadap anak. Dukungan tersebut dapat dipersepsikan oleh anak sebagai bentuk upaya pembentukan perilaku yang sesuai dengan diri anak dan lingkungan.

Dukungan sosial yang diberikan oleh orangtua terdiri dari informasi atau nasehat verbal dan nonverbal, bantuan nyata, atau tindakan yang diberikan oleh keakraban sosial atau didapat karena kehadiran orang yang mendukung serta memiliki manfaat emosional atau efek perilaku (Gottlieb dalam Marliyah, Dewi \& Suyasa, 2004). Menurut Sarafino (1998), dukungan sosial dapat diklasifikasikan ke dalam lima bentuk yang terdiri dari: dukungan emosional, dukungan penghargaan diri, dukungan instrumental, dukungan informasional, dan dukungan dari jaringan sosial.

Dukungan orangtua mempunyai korelasi terhadap perilaku makan, status gizi, serta perkembangan psikologis anak. Begitu pula dengan sikap orangtua terhadap perilaku makan anak, juga menjadi pusat dalam proses pembelajaran sosial. Sikap orangtua memberikan efek secara tidak langsung pada anak dalam memilih makanan yang disukai, serta kebiasaan makan anak. Sebagai contoh, anak-anak akan memilih jenis makanan yang berbeda pada saat sedang diperhatikan oleh orangtua. Selain itu, terdapat korelasi positif antara kebutuhan gizi anak dan orangtua, dengan usaha orangtua dalam meningkatkan asupan gizi anak (Ogden, 2007).

Anak dapat melihat dan menilai orangtua dalam memberikan dukungan mengenai perilaku mengkonsumsi buah secara langsung. Menurut Robbins dan Judge (2008), persepsi adalah proses di mana individu mengatur dan menginterpretasikan kesan-kesan sensoris untuk memberikan arti bagi lingkungan. Selain itu definisi persepsi diungkapkan oleh Seamon dan Kenrick (dalam Marliyah dkk, 2004), yang 
menjelaskan bahwa persepsi melibatkan proses organisasi dan interpretasi dari stimulus-stimulus untuk memberikan makna-makna tertentu. Persepsi memiliki peran penting dalam berhubungan dengan orang lain. Persepsi mengenai orang lain dan untuk memahami orang lain dikenal dengan persepsi sosial (Sarwono, dalam Marliyah dkk, 2004). Greenberg dan Baron (dalam Marliyah dkk, 2004), mendefinisikan persepsi sosial sebagai hasil dari proses mengkombinasikan, mengintegrasikan, dan menginterpretasikan informasi untuk mendapatkan pemahaman yang akurat mengenai orang lain.

Faktor-faktor yang mempengaruhi persepsi antara lain faktor internal, faktor eksternal, adanya pengalaman seseorang dimasa lampau, harapan seseorang, serta motif dan kebutuhan seseorang, di mana hal tersebut termasuk dalam faktor personal. Selain itu faktor yang mempengaruhi persepsi adalah faktor situasional (Robbins dalam Simbolon, 2008; Walgito, 1994; Rakhmat, 2011; Satiadarma, 2001).

Sikap merupakan salah satu hasil interpretasi persepsi anak yang mempengaruhi karakteristik pribadi. Menurut Aswatini dkk (2008), pengetahuan yang baik mengenai suatu hal akan menyebabkan seseorang memiliki sikap, sehingga akan berpengaruh terhadap keputusan untuk memunculkan perilaku. Untuk meningkatkan pengetahuan mengenai perilaku mengkonsumsi buah, dapat dilakukan dengan memberikan informasi yang dapat memberikan pemahaman mengenai manfaat buah, dengan disertai pedoman dalam bahasa yang mudah dipahami. Dengan menerima informasi tersebut, kemungkinan anak merubah sikap terhadap buah akan lebih besar, karena pandangan terhadap buah yang berubah. Namun, media yang digunakan harus relevan sehingga mudah dipahami oleh anak. Sebagai contoh, perubahan sikap terhadap konsumsi buah jeruk tidak disebabkan karena berubahnya pandangan anak bahwa buah jeruk itu enak dan murah, tetapi karena informasi tentang sifat lain seperti dapat mencegah sariawan, maka pengetahuan mengenai buah jeruk bertambah nilainya.

Menurut Azwar (2011), sikap terbentuk dari adanya interaksi sosial yang dialami oleh individu. Dalam interaksi sosial, terjadi hubungan saling mempengaruhi antara individu yang satu dengan yang lain. Pembentukan sikap dipengaruhi oleh beberapa faktor yaitu pengalaman pribadi, kebudayaan, orang lain yang dianggap penting, media massa, lembaga pendidikan dan lembaga agama, serta faktor emosional dalam diri seseorang.

Berdasarkan penjelasan mengenai persepsi, dukungan sosial orangtua, dan sikap anak terhadap konsumsi buah, dapat diasumsikan bahwa anak memiliki persepsi dengan cara melihat dan menilai bagaimana orangtua memberikan dukungan sosial. Misalnya, bagaimana anak mempersepsikan dukungan emosional dalam bentuk fisikal afeksi yang diberikan oleh orangtua dan seterusnya. Hal tersebut terkait dengan penilaian anak mengenai bentuk dukungan yang diberikan orangtua berdasarkan klasifikasi dukungan sosial.

Setelah anak menginterpretasikan dukungan sosial orangtua tersebut, anak akan membentuk sikap yang pada akhirnya memunculkan kecenderungan apakah anak memiliki sikap positif terhadap konsumsi buah atau sebaliknya.

Dengan demikian peneliti tertarik untuk melakukan penelitian mengenai hubungan persepsi anak mengenai dukungan sosial yang diberikan oleh orangtua dengan sikap anak terhadap perilaku mengkonsumsi buah.

\section{Rumusan Masalah}

Berdasarkan fenomena yang terjadi beberapa waktu belakangan ini, masih banyaknya anak-anak terutama yang tinggal di kota besar, lebih akrab dengan makanan cepat saji yang mengandung lemak tinggi, serta tidak mengandung komponen gizi yang tepat, pengetahuan tentang pentingnya konsumsi buah masih rendah, juga orangtua yang tidak membiasakan anak untuk mengkonsumsi buah sejak dini, selain itu juga 
hasil penelitian Epstein dkk (1996) yang menyatakan bahwa melalui partisipasi aktif dari orangtua, yaitu dengan memberi contoh dan turut serta dalam melakukan kebiasaan makan yang sehat, anak akan mengikuti kebiasaan sehat tersebut, maka terdapat masalah yang penting untuk diteliti yakni mengenai persepsi anak tentang dukungan sosial orang tua dengan sikap anak terhadap konsumsi buah.

\section{Pertanyaan Penelitian}

Apakah terdapat hubungan antara persepsi anak mengenai dukungan sosial orangtua dengan sikap anak terhadap konsumsi buah?

\section{Hipotesis}

Terdapat hubungan yang signifikan antara persepsi anak mengenai dukungan sosial orangtua dengan sikap anak terhadap konsumsi buah.

\section{METODE}

\section{Partisipan}

Partisipan dalam penelitian yaitu siswa sekolah dasar di Jakarta. Adapun usia partisipan yaitu 9-11 tahun. Metode yang digunakan dalam penelitian adalah metode penelitian korelasional. Teknik pengambilan sampel dalam penelitian ini menggunakan teknik proportionate stratified random sampling, yaitu sebuah teknik yang digunakan jika populasi mempunyai anggota yang tidak homogen dan berstrata secara proporsional (Sugiyono, 2007).

\section{Desain}

Alat ukur yang digunakan dalam penelitian ini adalah skala yang dibuat peneliti berdasarkan teori tentang persepsi anak mengenai dukungan sosial orang tua, dan sikap anak terhadap perilaku mengkonsumsi buah.

Pada penelitian ini digunakan validitas konstruk. Skala penelitian dengan validitas konstruk dapat digunakan untuk mengukur gejala sesuai definisi. Pengujian validitas konstruk dilakukan dengan cara meminta pendapat dari ahli mengenai aspek yang diukur berdasarkan teori tertentu. Setelah pengujian oleh ahli, dilakukan uji coba skala penelitian pada sampel dari populasi yang telah ditentukan. Data yang diperoleh dari uji coba dihitung menggunakan analisis faktor menggunakan komputer (Sugiyono, 2007). Menurut Nisfiannoor (2008), koefisien validitas $>0,20$ telah dianggap memuaskan. Jika hasil perhitungan diperoleh nilai $>0,20$, maka skala penelitian dapat digunakan dalam penelitan.

Berdasarkan uji coba skala persepsi anak mengenai dukungan sosial orangtua, diperoleh hasil bahwa 26 dari 68 aitem dinyatakan tidak berfungsi dengan baik, yaitu aitem 3, 5, 6, 8, 10, 11, 14, 15, 16, 17, 18, $20,21,22,25,26,27,28,29,31,32,34,35,37,38$, dan 40. Sedangkan pada uji coba skala sikap anak terhadap perilaku mengkonsumsi buah, diperoleh hasil bahwa 10 dari 60 aitem dinyatakan tidak berfungsi dengan baik yaitu aitem $4,7,9,15,18,22,23,33,38$, dan 53 . Salah satu contoh aitem yang digunakan yaitu "orangtua saya peduli dengan kebiasaan makan buah saya." 
Dalam melakukan pengujian reliabilitas, peneliti menggunakan metode internal consistency, yaitu dilakukan dengan cara mencobakan skala penelitian sekali saja, kemudian setelah data diperoleh kemudian dianalisis dengan teknik Alpha Cronbach. Hasil analisis tersebut dapat digunakan untuk memprediksi reliabilitas skala penelitian (Sugiyono, 2007). Pengujian reliabilitas dilakukan dengan teknik Alpha Cronbach.

Untuk memperoleh koefisien reliabilitas yang besar, maka pada skala persepsi anak mengenai dukungan sosial orangtua dan sikap anak terhadap perilaku mengkonsumsi buah, masing-masing dibuang aitem-aitem yang tidak berfungsi dengan baik. Pada skala persepsi anak mengenai dukungan sosial orangtua, aitem yang dibuang berjumlah 26 (aitem 3, 5, 6, 8, 10, 11, 14, 15, 16, 17, 18, 20, 21, 22, 25, 26, 27, 28, 29, 31, 32, 34, 35, 37, 38, dan 40). Sedangkan pada skala sikap anak terhadap perilaku mengkonsumsi buah, aitem yang dibuang berjumlah 10 (aitem 4, 7, 9, 15, 18, 22, 23, 33, 38,dan 53). Salah satu contoh aitem yang digunakan yaitu "saya merasa senang jika makan buah". Berdasarkan uji coba skala, diperoleh hasil koefisien reliabilitas persepsi anak mengenai dukungan sosial orangtua adalah 0,917 , sedangkan koefisien reliabilitas sikap anak terhadap perilaku mengkonsumsi buah adalah 0,940 .

\section{Prosedur}

Penelitian dilakukan pada Sabtu, 25 Agustus 2012 pukul 11.30 di SD 'C', Jakarta Pusat. Jumlah seluruh subjek adalah 70 orang. Terdapat beberapa karakteristik subjek penelitian, yaitu jenis kelamin laki-laki dan perempuan, serta usia 9 sampai 11 tahun.

\section{Teknik Analisis}

Penelitian yang dilakukan bertujuan untuk menguji korelasi antar variabel, maka teknik analisis statistik yang digunakan adalah Pearson Product Moment. Untuk membantu perhitungan, maka digunakan Statistical Product and Service Solutions (SPSS) versi 20.0 untuk Windows.

\section{ANALISIS \& HASIL}

Berikut dijelaskan lebih lengkap hasil yang diperoleh sehubungan dengan karakteristik-karakteristik tersebut, melalui tabel frekuensi beserta persentase tiap karakteristik.

Tabel 3. Deskripsi Usia dan Jenis Kelamin Subjek Penelitian

\begin{tabular}{lcccc}
\hline \multirow{2}{*}{ Data Demografis } & Variasi & Frekuensi & Persentase & Total \\
\cline { 3 - 5 } & & & (\%) & (\%) \\
\hline \multirow{4}{*}{ Usia } & 8 & 2 & 2,8 & \\
& 9 & 17 & 24,2 & \multirow{2}{*}{100} \\
& 10 & 20 & 28,5 & \\
& 11 & $\mathbf{2 2}$ & 31,4 & \\
\hline Jenis Kelamin & 12 & 1 & 11,4 & 100 \\
& 14 & 37 & 1,4 & \\
\hline
\end{tabular}


Berdasarkan tabel di atas, dapat disimpulkan beberapa hal. Pertama, mengenai usia. Karakteristik usia subjek penelitian adalah 9-11 tahun. Namun, terdapat subjek dengan usia di luar karakteristik (8, 12 dan 14 tahun). Hasil yang diperoleh adalah sebagian besar subjek penelitian berusia 11 tahun, yaitu berjumlah 22 orang.

Kedua, mengenai jenis kelamin. Karakteristik jenis kelamin subjek penelitian adalah laki-laki dan perempuan. Hasil yang diperoleh adalah subjek penelitian dengan jenis kelamin laki-laki lebih banyak daripada perempuan.

Tabel 4. Korelasi Persepsi Anak Mengenai Dukungan Sosial Orangtua dengan Sikap Anak terhadap Perilaku Mengkonsumsi Buah

\begin{tabular}{llcc}
\hline & & Total skor persepsi & Total skor sikap \\
\hline Total skor persepsi & Korelasi Pearson & 1 & $667^{* *}$ \\
& Sig. (2-pihak) & & 000 \\
& $\mathrm{~N}$ & 70 & 70 \\
\hline Total skor sikap & Korelasi Pearson & $667^{* *}$ & 1 \\
& Sig. (2-pihak) & 000 & \\
& $\mathrm{~N}$ & 70 & 70 \\
\hline
\end{tabular}

Berdasarkan hasil pengujian korelasi, diperoleh $r=0,667$ dan $p=0,000$. Oleh karena $p(0,000)<$ $\alpha(0,01)$, maka hipotesis diterima. Artinya, terdapat hubungan positif dan signifikan antara persepsi anak mengenai dukungan sosial orangtua dengan sikap anak terhadap konsumsi buah. Makin tinggi persepsi mengenai dukungan sosial orangtua, maka makin tinggi sikap anak terhadap konsumsi buah. Sebaliknya, makin rendah persepsi mengenai dukungan sosial orangtua, maka makin rendah sikap anak terhadap konsumsi buah.

\section{DISKUSI}

Berdasarkan pengujian hipotesis, diperoleh hasil bahwa terdapat hubungan yang signifikan antara persepsi mengenai dukungan sosial orangtua dengan sikap anak terhadap konsumsi buah. Sejalan dengan teori Ogden (2007) yang mengemukakan bahwa, dukungan orangtua mempunyai korelasi positif terhadap perilaku makan anak. Hal tersebut berarti, jika orangtua memberikan dukungan sosial dalam mengkonsumsi buah, maka anak akan memiliki sikap positif terhadap konsumsi buah.

Mengenai dukungan sosial orangtua terhadap konsumsi buah anak, secara umum dapat disimpulkan bahwa dukungan orangtua berperan penting dalam konsumsi buah pada anak. Secara khusus, dukungan sosial berupa dukungan emosional, penghargaan diri, instrumental, informasional, dan jaringan sosial, masingmasing memberikan kontribusi dalam mendukung konsumsi buah pada anak.

Pertama, indikator fisikal afeksi dalam dukungan emosional paling banyak dipilih oleh subjek. Menurut Sarafino (1998) serta Cutrona dan Suhr (dalam Trisna, 2003), indikator fisikal afeksi menggambarkan bagaimana anak-anak akan menyukai dukungan orangtua berupa pemberian senyuman, ciuman, atau sentuhan lembut, ketika anak mengkonsumsi buah. Hal tersebut dapat memberikan rasa nyaman pada anak, serta memberikan semangat bagi anak untuk mengkonsumsi buah. 
Kedua, indikator pemberian pujian memiliki kecenderungan dipilih oleh mayoritas subjek pada dukungan penghargaan diri. Orangtua menyatakan hal-hal positif seperti memberikan pujian pada anak. Pujian yang diberikan oleh orangtua, mampu memberikan perasaan berharga bagi anak sehingga menimbulkan rasa percaya diri anak dalam mengkonsumsi buah (Sarafino, 1998, Cutrona dan Suhr (dalam Trisna, 2003)).

Ketiga, indikator kesediaan pada dukungan instrumental, paling memiliki kecenderungan dipilih oleh subjek. Menurut Sarafino (1998) serta Cutrona dan Suhr (dalam Trisna, 2003), dukungan yang diberikan orangtua berupa kesediaan dalam membantu anak dalam mengkonsumsi buah. Misalnya, orangtua membantu untuk menyediakan buah untuk anak atau membantu memotongkan buah.

Keempat, indikator mengajarkan memiliki kecenderungan dipilih oleh mayoritas subjek pada dukungan informasional. Pemberian dukungan berupa nasehat, arahan atau saran, dapat membantu anak dalam memperoleh informasi mengenai pentingnya konsumsi buah. Misalnya, anak memperoleh pengetahuan mengenai manfaat dari orangtua, atau melihat bagaimana orangtua mengajarkan anak untuk memiliki kebiasaan mengkonsumsi buah (Sarafino, 1998, Cutrona dan Suhr (dalam Trisna,2003)).

Kelima, indikator kehadiran paling memiliki kecenderungan dipilih oleh subjek pada dukungan jaringan sosial. Kehadiran orangtua memiliki peranan penting bagi anak. Menurut Sarafino (1998) serta Cutrona dan Suhr (dalam Trisna, 2003), orangtua yang bersedia untuk menghabiskan waktu bersama dalam mengkonsumsi buah, dapat menimbulkan perasaan memiliki, karena anak menjadi kesatuan dengan orangtua dalam keluarga.

Selain pembahasan mengenai dukungan sosial orangtua, terdapat pembahasan mengenai sikap anak terhadap konsumsi buah. Secara umum, dapat disimpulkan bahwa sikap anak terhadap konsumsi buah cenderung netral. Secara khusus, sikap siswa terhadap konsumsi buah lebih menekankan pada komponen perilaku. Komponen perilaku memiliki skor rata-rata tertinggi dalam sikap anak terhadap konsumsi buah yaitu 43,40. Komponen afektif memiliki skor rata-rata dalam sikap anak terhadap konsumsi buah sebesar 41,43. Komponen kognitif memiliki skor rata-rata dalam sikap anak terhadap konsumsi buah sebesar 33,67.

Komponen perilaku meliputi bentuk perilaku yang dapat dilihat secara langsung. Misalnya, perilaku makan buah setiap hari, atau perilaku membawa bekal buah ke sekolah. Perilaku yang dimunculkan oleh anak, tidak terlepas dari peran orangtua dalam memberikan dukungan. Kebiasaan orangtua dapat membentuk sikap anak untuk melakukan hal yang sama dengan orangtua, yaitu mengkonsumsi buah.

\section{SIMPULAN \& SARAN}

\section{Simpulan}

Penelitian menyimpulkan bahwa terdapat hubungan yang signifikan antara persepsi anak mengenai dukungan sosial orangtua dengan sikap anak terhadap konsumsi buah.

\section{Saran}

Bagi orangtua diharapkan dapat memberikan dukungan yang seimbang, baik secara emosional, penghargaan diri, instrumental, informasional, maupun jaringan sosial. Orangtua dapat mengajarkan anak mengenai jenis buah-buahan, manfaat, serta bentuk olahan dari buah yang dapat dikonsumsi sebagai alternatif. Diharapkan orangtua dapat memberikan reward berupa senyuman, pujian, dan lainnya sehingga anak menjadi lebih termotivasi untuk mengkonsumsi buah. 
Orangtua juga diharapkan tidak memaksa anak, namun mengajak dan merangkul untuk menumbuhkan kebiasaan mengkonsumsi buah sejak dini. Orang tua dapat melakukan pendekatan secara perilaku dengan cara menyediakan buah untuk anak, membawakan bekal buah ke sekolah, dan mengkonsumsi buah setiap hari bersama anak. Diharapkan orangtua meluangkan waktu dengan berada di sisi anak untuk mengkonsumsi buah bersama.

Bagi anak diharapkan anak mulai untuk membiasakan mengkonsumsi buah setiap hari, sebagai bagian dari usaha menjaga kesehatan. Diharapkan anak dapat mencari dan menggali informasi yang tepat mengenai konsumsi buah, serta memiliki penilaian yang positif terhadap konsumsi buah. Anak juga diharapkan berpartisipasi dengan orang tua untuk membeli buah, menyediakan buah untuk dikonsumsi, memilih buah yang disukai, dan lain-lain.

Bagi sekolah, diharapkan sekolah mengadakan program promosi buah-buahan yang menarik, sebagai bagian dari upaya menjaga kesehatan. Sekolah dapat membuat peraturan seperti meminta siswa membawa bekal buah ke sekolah. Sekolah dapat melakukan program rutin pembiasaan mengkonsumsi buah di sekolah, seperti pekan buah-buahan dan sebagainya. Program tersebut diikuti oleh warga sekolah (kepala sekolah, guru, siswa, dan karyawan). Diharapkan sekolah dapat bekerja sama dengan pengelola kantin untuk menyediakan jenis buah-buahan kesukaan anak-anak, maupun produk olahan buah seperti jus, kue, puding, dan lain-lain.

Bagi pemerintah, diharapkan pemerintah melakukan penyuluhan mengenai konsumsi buah-buahan secara berkala dan menyeluruh di tiap wilayah dengan bantuan pihak-pihak lain. Diharapkan pemerintah dapat melanjutkan program pedoman umum gizi seimbang dan menerapkan pada kurikulum di sekolah. Diharapkan pemerintah dapat menampilkan secara berkala iklan layanan masyarakat mengenai promosi buah-buahan di media cetak maupun media elektronik. Pemerintah dapat melakukan promosi kesehatan dengan fokus pada perilaku konsumsi buah, karena dengan mencontohkan perilaku maka manfaat yang diterima akan lebih efektif. Misalnya, bekerja sama dengan pihak-pihak lain untuk membuat video yang menampilkan anak-anak sedang mengkonsumsi buah.

Bagi penelitian selanjutnya, saran yang diberikan adalah: sebaiknya dilakukan penelitian mengenai kelompok asupan makanan sehat lainnya seperti sayur-sayuran, produk makanan hewani, dan lain-lain; dapat dilakukan perbandingan dengan siswa sekolah dasar di Jakarta, maupun di daerah lainnya agar memperkaya hasil penelitian serta generalisasi yang lebih luas; dapat dilakukan perbandingan antar kelompok usia lain yang lebih tinggi tingkatan usianya, seperti kelompok remaja; mempertimbangkan faktor sosial ekonomi subjek penelitian, yang berkaitan dengan lokasi pengambilan data; dapat dikembangkan aspek-aspek baru yang dapat dikategorikan dalam dukungan sosial orangtua, dapat dilakukan penelitian mengenai faktor-faktor lain yang berhubungan dengan pembentukan sikap anak, misalnya, pengalaman pribadi, kebudayaan, orang lain yang dianggap penting, media massa, lembaga pendidikan dan agama, dan faktor emosional; terakhir yang cukup penting, penelitian lebih lanjut dapat dilengkapi penelitian dengan metode lainnya, seperti observasi perilaku dan wawancara, untuk cross-check jawaban atau data, sehingga dapat memperkaya serta memperdalam hasil penelitian.

\section{DAFTAR PUSTAKA}

Ahmad, E. Yanuar. (2011). Diet Sehat untuk Anak. Yogyakarta: Penerbit Kanisius.

Aswatini., Noveria, M \& Fitranita. (2008). Konsumsi Buah di Masyarakat dalam Konteks Pemenuhan Gizi Seimbang. Jurnal Kependudukan Indonesia Vol.III, No.2. 
Azwar, Saifuddin. (2011). Sikap Manusia Teori dan Pengukurannya. Yogyakarta: Pustaka Pelajar.

Badan Perencanaan Pembangunan Nasional. (2007). Rencana Aksi Nasional Pangan dan Gizi 2006-2010. Jakarta.

Epstein, L.H., Valoski, A., Wing, RW., (1996). Ten-year Outcomes of Behavioral Family-based Treatment for Childhood Obesity. Health Psychology, Vol.13, No.5, 373-383.

Khomsan, Ali., Anwar, F., Sukandar, D., Riyadi, H \& Mudjajanto, ES. (2006). Studi Tentang Pengetahuan Gizi Ibu dan Kebiasaan Makan pada Rumah Tangga di Daerah Dataran Tinggi dan Pantai. Jurnal Gizi dan Pangan, 1(1), 23-28.

Marliyah, L., Dewi, Fransisca IR., Suyasa, P Tommy. (2004). Persepsi Terhadap Dukungan Orangtua dan Pembuatan Keputusan Karier Remaja. Jurnal Provitae No.1.

Nisfiannoor, Muhammad. (2008). Pendekatan Statistika Modern. Jakarta: Salemba Humanika.

Norell, JE. (1984). Self Disclosure: Implications for The Study of Parent-Adolescent Interaction. Journal of Youth and Adolescent, Vol.3, No. 2.

Ogden, Jane. (2007). Health Psychology a Textbook 4th Edition. England: Open University Press.

Papalia, Diane.E.,Olds, Sally.W \& Feldman,Ruth.D. (2009). Human Development Edisi 10. Jakarta: Salemba Humanika.

Rakhmat, J. (2011). Psikologi Komunikasi. Edisi Revisi. Bandung: PT Remaja Rosdakarya.

Sarafino, EP. (1998). Health Psychology : Biopsychosocial Interactions (3rd ed). New York: John Wiley $\&$ Sons.

Sartika, Ratu Ayu Dewi. (2011). Faktor Risiko Obesitas pada Anak 5-15 Tahun di Indonesia. Makara, Kesehatan, Vol.1, No.1, 37-43.

Satiadarma, M.P. (2001). Persepsi Orang Tua Membentuk Perilaku Anak. Jakarta:Pustaka Populer.

Simbolon, Maropen. (2008). Persepsi dan Kepribadian. Jurnal Ekonomi dan Bisnis,Vol.2, No.1.

Sugiyono. (2007). Statistika untuk Penelitian. Bandung: CV Alfabeta.

Susana, Tjipto \& Hadiyono, J.E. Prawitasari. (2002). Efektivitas Kombinasi Metode Informasi Gizi dan Pelatihan Dukungan Sosial dalam Peningkatan Interaksi Ibu Anak dan Status Gizi Anak. Jurnal Sosiohumanika, 15(2).

Trisna, Y. (2003). Dukungan Sosial dan Stress Akademik pada Anak SD. Jakarta: Fakultas Psikologi Unika Atma Jaya. Skripsi.

Walgito, B. (1994). Psikologi Suatu Pengantar. Yogyakarta: Andi Offset.

\section{Internet}

Biro Pusat Statistik. (2012). Persentase Rata-rata Pengeluaran Per Kapita Per Bulan Menurut Kelompok Makanan di Provinsi DKI Jakarta. http://jakarta.bps.go.Id/Index.p hp?bWVudT0yMzEyJnBhZ2U9Z GF0YSZzdWI9MTImaWQ9OTE= diunduh tanggal 9 April 2013 
